\title{
The Impact of Consolidation Industrial Jordanian Companies on Profitability and Liquidity Ratios
}

\author{
Rana M. Airout ${ }^{1}$ \\ ${ }^{1}$ Assistant professor, Accounting Department, University of Philadelphia, Amman, Jordan \\ Correspondence: Rana M. Airout, Assistant professor, Accounting Department, University of Philadelphia, \\ Amman, Jordan.
}

Received: December 12, 2016

Accepted: March 6, 2017

Online Published: March 27, 2017

doi:10.5539/ibr.v10n4p183

URL: https://doi.org/10.5539/ibr.v10n4p183

\begin{abstract}
This research aims to explore and concentrated on the impact of consolidate industrial Jordanian companies, on financial performance reflect on profitability and liquidity ratios and made a comparison between pre consolidate and post consolidate companies, for four industrial consolidate companies were included in the sample. Three years pre and post-consolidation data is used to test the effect. The Data took from the annual financial statements for these companies, and the data was processed by using SPSS program.

The findings indicated that there are significant differences in the profitability of consolidated industrial companies before and after consolidation and there are significant differences in the liquidity of consolidated industrial companies before and after consolidation.
\end{abstract}

Keywords: profitability ratios, liquidity ratios, consolidation

\section{Introduction}

The world had faced in the last twenty years a lot of changes that effect on the nature of business and the nature of companies, as the evolution at all levels of economic, social, cultural, technical, and the concomitant development of technical and technological progress, in front of all these variables had to be the development of work tools.

As the result of that, escalated in recent, many companies start merging with other companies for many reasons, to keep up with the change that is happening in the economy, an essential part of the development type companies.

Lin and other define the business combination as merging two or more enterprises with infrastraction, operation and activities to become one enterprise.

Under IFRS 3 the business combination define as one or more businesses are control on same Transactions that owned by two or more business to share earnings and profits, losses and expenses. [IFRS 3].

Beams remind four types of combination as the following:

1- Merger type one: (known as an reorganization) a business combination through asset acquisition , that acquires company's assets and often liabilities.

2- Merger type two: that acquires all stock and then transfer assets and liabilities to its own books

3- Acquisition more than 50\%: a business combination that creates a new company in which none of the previous companies survive. So, it looks like A + B = C (here, distinct companies A and B consolidate into a new company, C)

4- Control ownership: establishes contractual control over variable interest to corporate in activities.

Generally accepted accounting principles (GAAP) require consolidated financial statements from parent companies that own or control subsidiary companies or have controlling interests in joint ventures and strategic partnerships. To report only the financial information of the parent company tells only part of the story of the entire enterprise since each subsidiary contributes both income and liabilities to the financial strength of the parent. 


\section{Research Problem}

The effecting nowadays of globalization significantly the pattern of competition, and open market to any company that has the ability to permeate new market and Theoretically, it is improve the performance of the company; for this reason the study highlights the role of consolidation to keep companies' sustainability by improving their financial performance. Therefore, the researcher in this context will make an attempt to analyze the impact of consolidation on the financial performance of the industrial Jordanian companies, so the study problem can be identified by the following question:

1- Did the consolidated Jordanian companies success to improve the financial performance of these companies?

\section{Research Hypotheses}

H01: There are no significant differences in the profitability of consolidated companies before and after consolidation.

H02: There are no significant differences in the liquidity of consolidated companies before and after consolidation.

\section{Methodology}

This study use the analytical statistical method using SPSS program, to congruent the aims the study data had been gotten from four consolidation cases occurred in Jordan.

\section{Study Sample}

The sample of this study includes two Jordanian consolidation cases:

1- Industrial Delel Complex, and Middle East Complex for industry and trade (2007)

2- Jordan International Industries, and Jordanian International Company for Tourism \& Real Estate Investment (2006)

3- Rum for mineral industries, and Ala Adin industries. (2001)

4- International Tobacco \& Cigarettes, and Al- Eqbal Investment Company (2000)

\section{Data Source}

Data obtained from the two main sources:

1- Ministry of the trade and industry

2- GUIDE of Amman bursa published and exist in the site of Amman bursa by downloading these data.

\section{The Literature Review and Previous Studies}

\subsection{Introduction}

The business become more riskier than ever because the industrial revolution that consider as turning point in business structure, That reflect to increased volume of production, created huge competition for customers, development in technology, increase investment involved in acquiring a factory and machinery discouraged for many new undertakers from entering competitive fields.

These factors all combined to rise the trend of consolidation. That made all Businesses over the world combined into trusts and corporations, and pooled resources to limit, and maybe to eliminate competition, or maybe creates industry-wide monopolies.

\subsection{History of Consolidation}

In the past, the simple economics in the world reflect on the simple nature of transaction of the companies, and almost all companies were Limited contribution (individual companies) owned by one owner or two owners.

In 1929 the great depression comes to collapse the biggest companies in American exchange market, that effect in the type of dealing businesses between each other, and that encourage the companies to increase the corporation between them to resolve the fallout from great depression, Especially with the advent of public shareholding companies, many companies are merging tougher to increase the share stock in the market exchange.

In 1973 when FASB begin to put the basic international accounting standard, it took in advance the simple merging that happened to some companies and put the reference standard for embedded companies in determining the mechanism of dealing which has encouraged other companies to merge to the existence of 
standards that define how to integrate and disclosed in the financial statements.

\subsection{Considerations of Consolidation}

For the companies that decide to consolidate, it must take in advance many issues, first, the type of business that the companies work with it, and the company that may want to consolidate make feasibility study if the products or services are appropriate to consolidate, for increasing the successful. The second issue, how the consolidation companies treat the different culture of employees in the companies specially when the companies are located in a different continent from the other company.

The fired issue, how much the collaboration will be the management of the consolidation companies, to achieve the common goals. The four issue, the extent to which the merged companies in compliance with international standards. So by these issues must he companies consider them when consolidation to gain more than its loss.

The fourth issue, Feasibility study of the extent of dilution of expenses and potential losses resulting from the merger and excellence among asset-integrated companies.

Finally, Must take into account the size of the merged companies, because the difference in the size of companies that can significantly affect the reflection on the financial and productive, monetary and strategic aspect of the company.

\subsection{Consolidation Significance}

Improving the future performances are the main reason of why many companies consolidate, So consolidate companies are always seeking to increase assets, gains and profits. Some consolidate companies are focus to increase intellectual property that contain trademarks and patents, to further improve the product and innovation in the management of production lines.

For other reason some consolidate companies went to get rid of the environmental, legal and tax problems by decreasing the expenses and the cost that will afford one company, by spreading these cost over consolidate facilities, and encourage companies to apply new techniques that increase the production and reduce waste.

The consolidation also development the strategies by taking ideas outside their organization so it will reflect positively on the companies repetition that increase market share for consolidated companies, or to grow company culture or encourage the investor to invest or increase the investment in consolidate companies.

Also the consolidation significant is to improve the technology that reflect on the production and administrative organizations and the improvement of the functional structure and increase the effectiveness of good governance.

Also the consolidate companies search with this consolidation to achieve the competitive advantage for its activates by rise the knowledge innovation to improving business performances

On the other hand, the successful consolidation and merging give an opportunity to companies to survival by eliminate the losses and increase the profit by using many strategies.

Finally, the successful competition resulted from consolidation companies may create a competitive advantage and creation in the product and services in the companies.

\subsection{The Consequence from Consideration}

The is no doubt that the companies when its decided to consolidate, will effect in all sides by the following:

1- The structure of the consolidate companies will change be merging two different structure into one complex structure, that result to create may sections, departments, create many jobs and Senior management positions

2- The management of the consolidate companies will change by The division of power and public administration merged company to the partners' shares resulting from the merger.

3- The polices and strategies in the consolidate companies will be different on the original companies before consolidate such as the marketing strategy will expand to include the largest number of area covered by the merged company.

4- Distribution of staff will differ between the merged companies could be an increase in the training of new employees at the combined company functions.

5- The quantitative and qualitative of the assets will be change in the consolidated companies.

6- Quality of products and services offered by the merged companies will vary, which can be reflected on the increasing expense of research and development. 


\subsection{Previous Studies}

- Yusuf Hroot (2016) "The Impact of Mergers on Financial Performance of the Jordanian Industrial Sector"

This study aimed to focus on merging companies in industrial sector in Jordan and who its effected on financial performance ( market prospect, profitability, liquidity, leverage, efficiency ratios),and made a comparison between pre and post- merging four seven companies among two years before and after.

It used SPSS program to analysis data, and the finding of this study, concluded that the merging effect positively to these companies that reflect on increasing the ratios that took in this study.

-Sunday Ajao and Adewale Emmanuel (2013) "Banking Industry Consolidation and Financial Performance of Selected Quoted Banks in Nigeria"

The study aimed to reflect the financial performances that contain in this study (net profit margin, return on assets, return on capital employed, shareholder's fund, total assets) on pre and post consolidation . the study depend on financial stamen of banks annual reports and use a spss program in the statistical analyze. The result of the study, that there was a good impression on the consolidation on banking industry The study, recommended to increase the consolidation between companies specially the weak companies to increase corporate governance and transparency in their reports.

- Al-Dabas (2012), "Impact of integration on the performance of companies and their profits"

This study discuss the impact of integration on the performance of companies and their profits, that included the impact of the merger on performance and on the profit of companies, the researcher use Tobin's-Q model to measure assumptions, The sample of this study are: Industrial Delel Complex, and Middle East Complex for industry and trade, which happened in the year 2007. That took two years before the event and one year after the event to measure any impact on profitability and performance by SPSS program the results: there is no relationship between merger and perform of the companies, also there is no relationship between merger and profitability of the companies. It is return for the weak financial position of these companies before the merger, then merger.

-Tsai-Mei Linet al. (2011). "Enhancing performance through merger and acquisition or strategic alliances? In knowledge innovation based"

This study make a comparison of merging and acquisition on stock prices and stock trading volumes from 1993 to 2008. By using methodology of models for The standardized cumulative average abnormal returns (SCAR) and the model of The standardized cumulative average abnormal volumes ( SCAV.) the sample of the study are the industrial sector specially the non-electronics companies the study resulted that there is a strong relationship between merging and acquisition and SCAR and SCAV.

The recommendation of the study to understands the models that used previously in the research and adopted by all companies consolidated that want to increase the profits.

-Joshua Okpanachi (2011) "Comparative analysis of the impact of mergers and acquisitions on financial efficiency of banks in Nigeria"

This study the financial efficacy that contain ( gross earnings, profit after tax and net assets ) by compare the the pre consolidate and post consolidate by use the annual reports that published in Nigerian exchange stock, the sample of the study are banks, this study use SPSS program to fine the differences, the result of the study are positive on financial efficacy, and the study recommended to expand consolidation between banks to improve the quality of the profits

-Luis Santo-Pinto, (2010) "The impact of firm cost and market size asymmetries on national mergers in three-country model"

This study aimed to fine the impact capital and the size of companies on merger decisions the study use the methodology of model that define the relation between capital and size variables on the decisions, the sample of this study, are many companies from the third world that took their financial statements from there exchange markets belong to these companies. The study fine many results as following: the companies that have a huge capital Trent to merging more than the companies with the small capital because the regulation that exit in the large companies that encourage to merge more than the small companies, and the companies that have a large capital and size, have more interest in merging than the smallest companies.

-John Kwoka and Michael Pollitt (2010) "Do mergers improve efficiency? Evidence from restructuring the US electric power sector" 
This paper fined impact of merger on the efficiency of the companies in electricity sector in America during the period 1994-2003. The methodology used by analyzing total cost and profits, among years by divided it of pre consolidate and post consolidate between electric consolidated companies and electric non- consolidated companies. The results of the study are fined the efficiency of consolidation and merging to . improved cost performance.

-Nicholas F. et al. (2009) "Operating performance changes associated with corporate mergers and the role of corporate governance"

This study fined the impact of principles of corporate governance on consolidate firms by testing (board ownership, board size, and block-holder control). The results of the study are fined the significance impact principles of corporate governance to improve the consolidation technics between companies.

\section{-IQBAL ZAMIR (2008) "THE IMPACT OF CONSOLIDATION ONISLAMIC FINANCIAL SERVICES INDUSTRY"}

This study analyze the impact of consolidation on financial services industry, This study is based on a comparison of Islamic banks embedded in several countries in the world, so it took Islamic banks compact before and after the merger and compared with total assets of Islamic Murabaha and Leases ownership and other Islamic financial formulas, and was one of the most prominent results of this study include: taking into account the legal aspect and when the merger Islamic banks and stimulate diversity in the integration not only in the banking sector but in several sectors.

\section{Statistical Analysis}

To test the hypotheses of the study we applied SPSS on financial ratios of merged companies before and after consolidation, we used

Average of financial ratios before and after consolidation.

Independent t-test sample to compare the profitability and liquidity before and after consolidation.

Hypotheses Test

H01: There are no significant differences in the profitability of consolidated companies before and after consolidation.

To test this hypothesis we applied t-test for all the companies included in study sample, the results was as following:

Table 1. t-test Profitability ratio results for the sample

\begin{tabular}{|c|c|c|c|}
\hline Mean difference & Std error & $\mathrm{t}$-value & Sig \\
\hline $\begin{array}{l}\text { DALEL } \\
\text { Profitability ratio }\end{array}$ & 0.295 & -0.253 & 0.809 \\
\hline $\begin{array}{lc}\text { Jordan International Industries } \\
\text { profitability ratio } & 0.159 \\
\end{array}$ & 0.202 & 0.787 & 0.475 \\
\hline $\begin{array}{ll}\text { Rum for minerals industries } \\
\text { profitability ratio } & 0.116\end{array}$ & 0.046 & -2.513 & 0.066 \\
\hline $\begin{array}{l}\text { International Tobacoo \& Cigarettes } \\
\text { profitability ratio }\end{array}$ & 0.044 & -2.057 & 0.109 \\
\hline
\end{tabular}

We notice that the effect of consolidation on the companies' profitability is not significant for all companies, because:

- For al Delel complex, the mean difference is (-0.0746) and Sig is (0.809) greater than 0.05 .

- For Jordan International Industries, the mean difference is $(0.159)$ and Sig is $(0.475)$ greater than 0.05 .

- For Rum for minerals industries, the mean difference is $(0.116)$ and Sig is $(0.202)$ greater than 0.05 .

- For International Tobacoo \& Cigarettes the mean difference is $(0.159)$ and Sig is $(0.475)$ greater than 0.05 .

So we can conclude that there is no significant effect of consolidation on the profitability of consolidated companies. Then the null hypothesis is accepted.

H02: There are no significant differences in the liquidity of consolidated companies before and after consolidation. 
Table 2. t-test Liquidity ratio results for the sample

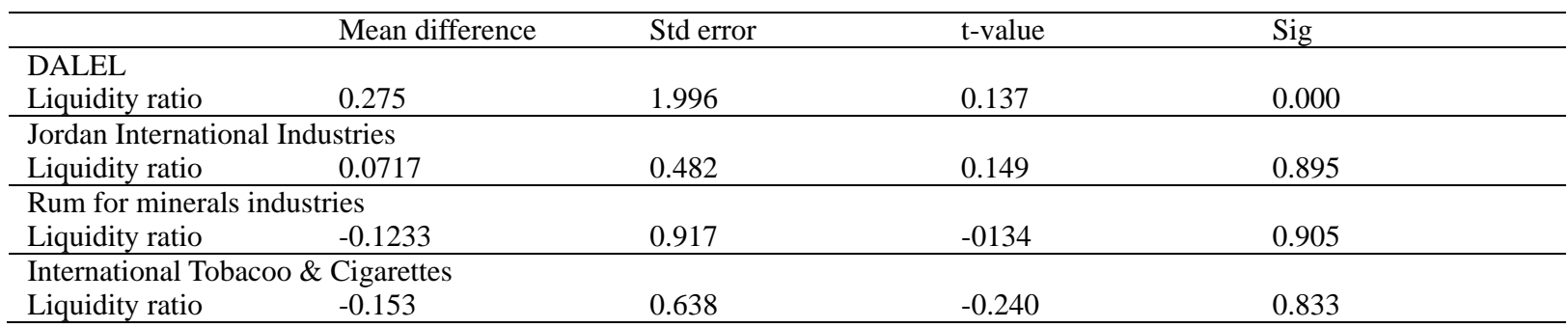

We notice that the effect of consolidation on the companies' liquidity is not significant for all companies except for Delel complex, because:

- For al Delel complex, the mean difference is $(0.275)$ and Sig is (0.000) greater than 0.05.

- For Jordan International Industries, the mean difference is (0.0717) and Sig is (0.895) greater than 0.05 .

- For Rum for minerals industries, the mean difference is (-0.1233) and Sig is (0.905) greater than 0.05 .

- For International Tobacoo \& Cigarettes the mean difference is (0.833) and Sig is (0.475) greater than 0.05 .

So we can conclude, in general, that there is no significant effect of consolidation on the liquidity of consolidated companies. Then the null hypothesis is accepted.

\section{Conclusion}

Based on the collected data and statistical analysis and hypothesis testing we reach to the following results:

1-There are significant differences in the profitability of consolidated industrial companies before and after consolidation.

2-There are significant differences in the liquidity of consolidated industrial companies before and after consolidation.

\section{Recommendations}

1-expand the consolidation between companies in Jordan cause many cases improve that the consolidation reflect positively on financial position for consolidate companies.

2-improve the regulation that encourage the consolidation between companies such as provide tax breaks.

\section{References}

Hroot, Y. (2016). The Impact of Mergers on Financial Performance of the Jordanian Industrial Sector. International Journal of Management \& Business Studies, 6, 9-13.

Tsai-Mei, L., \&, Hsiao, C., \& Ching, L. (2011). Enhancing performance through merger and acquisition or strategic alliances? In knowledge innovation based. African Journal of Business Management, 5, 14-17.

Kwoka, J., \& Pollitt, M. (2010). Do mergers improve efficiency? Evidence from restructuring the US electric power sector, International Journal of Industrial Organization, 28, 645-656. https://doi.org/10.1016/j.ijindorg.2010.03.001

Sufian, F., \& Habibullah, M. (2009). Do mergers and acquisitions leads to a higher technical and scale efficiency? A counter evidence from Malaysia. African Journal of Business Management, 3, 340-349.

Ibiwoye, A., \& Adeleke, I. (2008). Is insurance Nigeria's next capital market 'honey pot'? An investigation using daily stock data. African Journal of Business Management, 2, 157-164.

Carline, N., Linn, S., \& Yadav, P. (2009). Operating performance changes associated with corporate mergers and the role of corporate governance, Journal of Banking \& Finance, 33, 1829-1841. https://doi.org/10.1016/j.jbankfin.2009.03.012

Alam, G. (2009). The role of science and technology education at network age population for sustainable development of Bangladesh through human resource advancement. Scientific Research. Essays, 4, $1260-1270$.

Ho, L. (2008). What affects organizational performance? The linking of learning and knowledge management, Ind. Manage, 3, 1234-1254.

Krishnan, R., \& Krishnan, J. (2004). The influence of mergers on firms' product-mix strategies, Strategic management Journal, 6, 587-611. https://doi.org/10.1002/smj.410 
Lin, C., \& Wang, Y. (2009) Shareholder wealth effect of M \& A in Taiwanese listed firms. J. Inform. Optim. Sci., 1, 109-114. https://doi.org/10.1080/02522667.2009.10699868

Omerzel, D., \& Antonc `ic, B. (2008) Critical entrepreneur knowledge dimensions for the SME performance. Industrial Management \& Data Systems, 9, 1182-1199. https://doi.org/10.1108/02635570810914883

Pricewaterhouse, C. (2007). Going for growth: The outlook for M\&A in the financial services sector in Asia, UK.

Puranam, P., Singh, H., \& Zollo, M. (2006). Organizing for innovation: managing the coordination-autonomy dilemma in technology acquisitions. Academic Management, 2, 263-280. https://doi.org/10.5465/AMJ.2006.20786062

Santo-Pinto, L. (2010). The impact of firm cost and market size asymmetries on national mergers in three-country model. International Journal of Industrial Organization, 28, 682-694. https://doi.org/10.1016/j.jindorg.2010.03.012

Ajao, S., \& Emmanuel, A. (2013). Banking Industry Consolidation and Financial Performance of Selected Quoted Banks in Nigeria. Journal of Applied Finance \& Banking, 3, 219-238.

Okpanachi, J. (2011). Comparative analysis of the impact of mergers and acquisitions on financial efficiency of banks in Nigeria. Journal of Accounting and Taxation, 3, 1-7.

Zamir, I. (2008). The Impact Of Consolidation Onislamic Financial Services Industry. Islamic Economic Studies, 15. 
Appendix 1

\begin{tabular}{|c|c|c|c|c|}
\hline \multirow[t]{2}{*}{ Ratio } & Industries Delel Complex & & \multicolumn{2}{|c|}{ POST COSOLIDATION } \\
\hline & 2005 & 2006 & 2007 & 2008 \\
\hline \multicolumn{5}{|l|}{ Profitability } \\
\hline $\mathrm{ROA}$ & 0.05 & 0.02 & -0.006 & 0.008 \\
\hline ROE & 0.07 & 0.02 & -0.07 & 0.009 \\
\hline ROI & 0.05 & 0.02 & -0.006 & 0.008 \\
\hline ROS & 0.94 & 0.91 & 0.93 & 0.61 \\
\hline \multicolumn{5}{|l|}{ Liquidity } \\
\hline CURRENT RATIO & 3.62 & 4.29 & 3.69 & 1.47 \\
\hline CASH RATIO & 0.02 & 0.01 & 3.06 & 0.81 \\
\hline
\end{tabular}

\begin{tabular}{|c|c|c|c|c|c|c|}
\hline \multirow[t]{2}{*}{ Ratio } & \multicolumn{5}{|c|}{ Jordan International Industries } & \\
\hline & 2004 & 2005 & 2006 & 2007 & 2008 & 2009 \\
\hline Profitability & & & & & & \\
\hline ROA & 0.06 & 0.045 & 0.034 & 0.019 & 0.023 & 0.047 \\
\hline ROE & 0.07 & 0.05 & 0.04 & 0.023 & 0.027 & 0.05 \\
\hline ROS & 0.76 & 0.56 & 0.58 & 0.09 & 0.12 & 0.37 \\
\hline Liquidity & & & & & & \\
\hline CURRENT RATIO & 1.81 & 2.23 & 1.56 & 1.53 & 1.46 & 2.67 \\
\hline CASH RATIO & 0.93 & 1.63 & 1.29 & 1.04 & 0.99 & 1.33 \\
\hline
\end{tabular}

\begin{tabular}{|c|c|c|c|c|c|c|}
\hline \multirow[t]{2}{*}{ Ratio } & & & \multicolumn{3}{|c|}{ POST COSOLIDATION } \\
\hline & 1999 & 2000 & 2001 & 2002 & 2003 & 2004 \\
\hline Profitability & & & & & & \\
\hline ROA & -0.056 & -0.055 & 0.049 & 0.0017 & 0.0207 & 0.0033 \\
\hline ROE & -0.12 & -0.11 & -0.10 & 0.003 & 0.035 & 0.006 \\
\hline ROS & -0.17 & -0.065 & -0.306 & 0.003 & 0.034 & 0.006 \\
\hline Liquidity & & & & & & \\
\hline CURRENT RATIO & 2.01 & 0.74 & 1.86 & 1.66 & 1.68 & 1.54 \\
\hline CASH RATIO & 0.285 & 0.001 & 0.331 & 0.387 & 0.390 & 0.310 \\
\hline
\end{tabular}

\begin{tabular}{|c|c|c|c|c|c|c|}
\hline \multirow[t]{2}{*}{ Ratio } & \multicolumn{6}{|c|}{ AL EQBAL } \\
\hline & 1998 & 1999 & 2000 & 2001 & 2002 & 2003 \\
\hline \multicolumn{7}{|l|}{ Profitability } \\
\hline ROI & 0.0103 & 0.0033 & 0.0295 & 0.0965 & 0.1258 & 0.0768 \\
\hline ROE & 0.00107 & 0.0043 & 0.00321 & 0.1724 & 0.1802 & 0.1247 \\
\hline ROS & 0.15 & 0.13 & 0.10 & 0.15 & 0.15 & 0.17 \\
\hline \multicolumn{7}{|l|}{ Liquidity } \\
\hline CURRENT RATIO & 0.20 & 1.42 & 0.75 & 0.96 & 1.17 & 1.08 \\
\hline CASH RATIO & 0.04 & 0.001 & 0.03 & 0.10 & 0.01 & 0.04 \\
\hline
\end{tabular}

\section{Copyrights}

Copyright for this article is retained by the author(s), with first publication rights granted to the journal.

This is an open-access article distributed under the terms and conditions of the Creative Commons Attribution license (http://creativecommons.org/licenses/by/4.0/). 